\title{
Homeownership, city integration, and the sense of happiness of migrants in urban China
}

\author{
Sihan Zhang ${ }^{1 *}$ (D) Chuanlu $\mathrm{Hou}^{2}$ and Jing Chen ${ }^{3}$
}

\author{
* Correspondence: \\ zhangsihan2016@ruc.edu.cn \\ ${ }^{1}$ Renmin Business School, Renmin \\ University of China, Address: No. 59, \\ Zhongguancun Avenue, Haidian \\ District, Beijing 100872, People's \\ Republic of China \\ Full list of author information is \\ available at the end of the article
}

\begin{abstract}
In the literature on the migrant phenomenon in China, homeownership, city integration, and sense of happiness have all been examined, yet the synergetic relationship among these three factors has not been fully discussed. This study uses the 2012 National Dynamic Monitoring Database of Migrants created by the National Health and Family Planning Commission of China to explore the cooperative relationship between migrants' homeownership, city integration and the sense of happiness. Generally, renting houses reduces migrants' sense of happiness. However, with migrants' greater integration into the place to which they have migrated, the sense of happiness of migrants who live in rental houses is enhanced to a greater degree than those who live in their own houses. This phenomenon is clear among migrants who have moved from less developed regions to developed regions and among those who have moved relatively longer geographical distances. This study demonstrates a city integration mechanism through which homeownership influences migrants' sense of happiness. We contribute to happiness economics research and propose a scientific basis for speeding up new urbanization as well as improving a housing system which encourages both house renting and purchasing in China.
\end{abstract}

Keywords: Homeownership, City integration, Sense of happiness, China, Rental house, Migrants, Urbanlization, Hukou

\section{Introduction}

Due to the household registration (hukou) system, there are two types of internal migrant populations in China: The first one is a group of people who migrate by transferring their hukou, and the second one is a mix of migrants whose hukou is still in their hometown. In this paper, we focus on the latter type of migrants. Since the 1990s, China has seen increasingly accelerated population movements. According to the 2016 China Migration Population Development Report, the number of migrants in China amounts to 247 million, accounting for $18 \%$ of the total population with the average migrant family size reaching 2.61. Also, according to the 2014 National New Urbanization Plan in China, there will be more than 200 million migrants to cities by 2020 with the movement of whole families more common. Such a large scale population flow contributes to the economic growth of the migration destination areas; however, the migrant population cannot be truly integrated into urban society and

(c) The Author(s). 2019 Open Access This article is distributed under the terms of the Creative Commons Attribution 4.0 International License (http://creativecommons.org/licenses/by/4.0/), which permits unrestricted use, distribution, and reproduction in any medium, provided you give appropriate credit to the original author(s) and the source, provide a link to the Creative Commons license, and indicate if changes were made. 
identified as locals because of the restrictions of the household registration system. This leads to a pseudo-urbanization phenomenon in migration destination cities. At the same time, with apparent differences in income, culture and beliefs between migrants and locals, migrants are prone to be anxious in unfamiliar places. Therefore, a sense of happiness for these migrants may be weakened to some extent. This uncomfortable sentiment may stimulate social contradictions and even contribute to the formation of various social strata. For instance, "Beipiao," a popular term describing this integration situation in Beijing and the psychology of the migrant population, is used for a group of migrants who live without fixed residences and are unable to integrate into the local society and thus lack the sense of happiness and security. In addition, it reflects the fact that having proper housing determines, to some extent, whether a migrant can integrate into a new place and participate in the social life of that place thoroughly or not.

Since the State Council issued the house purchase restriction policy ("Guo Shi Tiao") in 2010, local governments have also introduced relevant house purchase policies to prevent housing prices from becoming overheated. Generally, most of the housing purchase restriction policies limit the number of houses a resident can buy. For those people without hukou, the number of houses they are permitted to purchase is always less than that of local residents. The purchasing procedure is also more complicated and several cities do not allow residents without hukou to buy houses at all. This policy has been successful in supporting the government's stated goal, i.e., "housing is for living in, not for speculation," but it creates significant difficulties for migrants without hukou in integrating into their new places of residence.

Given the heterogeneity of the migration population in China, this paper uses the 2012 National Dynamic Monitoring Database of Migrants created by the National Health and Family Planning Commission of China, and explores the cooperative relationship between their homeownership, integration into the places they have migrated to (in this paper referred to as "city integration", as the most common type of migration in China is to urban areas) and sense of happiness. Firstly, our empirical work illustrates that renting houses indeed reduces migrants' sense of happiness; the sense of happiness of the migrant population who lives in rental housing, however, can be improved to a greater degree than those who live in their own houses. Therefore, in the long run, the conclusion that renting houses weakens migrants' sense of happiness depends on their levels of city integration. Secondly, we examine whether this phenomenon differs among different kinds of migrant populations. From the perspective of the heterogeneity of flow directions, we divide migrants into two subsamples. One includes migrants with an "ascending" migration experience, that is, migrating from less developed regions to developed regions; the other includes migrants with a "falling" migration experience, migrating from developed regions to less developed regions. With respect to flow distance heterogeneity, the migrant population can also be divided into two groups: people migrating on a small scale and people migrating on a larger scale. Our empirical evidence shows that compared to people who have "falling" experiences, the connection between housing and sense of happiness is more significant in those who have "ascending" experiences. In addition, this is especially obvious among people who have moved relatively longer geographical distances.

Generally, the existing literature notes that owning houses can significantly improve residents' sense of happiness for several different reasons. First, a fixed living place 
provides a family with a better living environment and quality of life. Therefore, a family member's subjective sense of happiness can be substantially improved (Bucchianeri 2009). Secondly, children who live in their own houses are less likely to have developmental problems, and perform better in school (Haurin et al. 2002; Stephen and Ezati 2017; Whelan 2017). Furthermore, in China, the relationship between education and housing status is close in that schools often only accept children whose families own a house in the school's neighborhood. In this way, their sense of happiness can be significantly enhanced. Thirdly, owning a house can improve homeowners' life satisfaction and encourage them to participate in voluntary and political activities to some extent (Rohe and Stegman 1994). Finally, compared with living in rental housing, purchasing a house and owning property can offer homeowners many benefits. Since housing has social value and a wealth effect, rising house prices can significantly reduce the sense of happiness of renters, but can significantly improve that of householders (Bostic et al. 2009). Also, housing has a mortgage function, which helps homeowners to alleviate liquidity constraints and reduce preventive savings, which contributes to a sense of happiness. While housing has both residential attributes and asset attributes, it is likely that it enhances a migrant's sense of happiness mainly via residential attributes rather than asset attributes.

Most of the domestic and foreign research on housing and the integration of migrants into a city comes from the perspective of housing status. In previous research it was found that having a place of residence is one of the prerequisites for peoples' social integration (Anderson 1993; Pleace 1998). Furthermore, researchers have explored the impacts of housing heterogeneity on city integration. For example, Dorvil et al. (2005) study four different living modes of patients with mental illness and find that different residence forms have different influences on the patients' integration. An appropriate residence is the basis of social integration. Yang (2015) explores the social integration of people with various housing types and finds that low-rent housing can improve migrant workers' city integration levels. In addition, there is literature that explores the relationship between housing and migrants' city integration from the perspective of integration barriers. House prices in first-tier cities have a screening effect on migrants. People who have migrated from rural areas to urban areas often have lower levels of integration into the city and poorer living environments than local residents. In addition, it is also found that residents' city integration and subjective sense of happiness also have significant positive correlations ( $\mathrm{Li}$ et al. 2018).

To sum up, a strong association between homeownership, city integration and sense of happiness has been found in previous research. This paper explores the cooperative relationship between migrants' homeownership, city integration and sense of happiness from three new perspectives. Firstly, we focus on the synergetic relationship between these three factors. Secondly, this paper examines the impact of homeownership on migrants' happiness from the perspective of city integration. Thirdly, we focus on heterogeneous migration experiences rather than on the characteristics of migrants. This paper further discusses happiness economics research. It also puts forward a scientific basis for speeding up new type of urbanization and improving a housing system which encourages both house renting and purchasing in China.

In this paper, Section 2 outlines the main hypotheses; Section 3 presents the data, variables and methods used; Sections 4 and 5 report and analyze the empirical findings 
including main tests and robustness tests. In Section 6, the main conclusions are made and policy recommendations are put forward.

\section{Hypothesis development}

Previous studies have confirmed that having private houses correlates positively with city integration. On the one hand, a migrant with a high degree of city integration is inclined to buy a house; on the other hand, owning a house in a migration destination is a necessity for the migrant to fully integrate into the new society. By buying and owning a house, migrants can acquire legal and fixed residences, end the transient period of their life in the unfamiliar city, and activate their city integration process. In the meantime, owning a house can significantly improve their subjective sense of happiness (Gan 2010). It is obvious that compared with people who have already bought their own houses, renters' average city integration levels and sense of happiness are lower, and the possibility for renters to enhance city integration and sense of happiness is larger. Accordingly, further promotion of city integration will improve renters' sense of happiness more rapidly than homeowners; migrants' city integration and sense of happiness should be complementary and synergetic. Based on the analyses above, we propose:

Hypothesis 1 The effect of city integration on a sense of happiness is different among migrants with different housing status. Improvement in city integration can impact the sense of happiness of renters more than that of homeowners.

Different migration directions impact the synergetic effect of city integration and housing status on migrants' sense of happiness. From the perspective of neoclassical economics theory, the direction of migration in China is closely related to the regional economy. People tend to migrate to more developed areas, namely from rural areas to cities, i.e., the urbanization process. However, with further optimization in industrial structure, the narrowing of the gap between rich and poor regions, more flexible employment modes, and the "backflow" experience of people migrating from developed areas to less developed areas has attracted increasing attention. The research on rural to urban migration generally shows that due to the differences in cultural customs, ideological make-up and living habits between inflow regions and outflow regions, it is difficult for people who have migrated from rural areas to truly integrate into urban life (Qin and Chen 2014). Studies on "backflow" migration mainly focuses on migrants who have returned to their place of household registration (generally their hometown) and finds that these people more easily adapt to their surroundings. The possible reasons are as follows: First, migrants did not have better living conditions in developed areas (Murphy 2002); second, they accumulated human capital, asset capital, social capital and natural capital while working and living in the developed areas (Kusmin 2007; Sun 2016); third, there are strong social networks (Michelacci and Silva 2007; Yu et al. 2016) and good investment opportunities (Wang and Fan 2006) in their hometowns where their hukou are located. Thus, with the combined effects of push-and-pull power, the difficulty of these migrants returning and integrating into their hometown is reduced. In view of the above, among the migrants with "ascending" migration experiences, compared with home owners, renters' sense of happiness will be enhanced more significantly with greater level of city integration. It is less obvious among people with "falling" experiences. Thus, Hypothesis 2 is as follows: 
Hypothesis 2 Improvement of city integration has a greater effect on enhancing the renters' sense of happiness among the migrants who migrated from underdeveloped areas to developed areas rather than those who moved from developed areas to underdeveloped areas.

In addition, depending on the distance of the migration, the effects of different housing condition on city integration and sense of happiness are also different. Most migrants have little communication with local residents in daily life and still mainly rely on and develop social networks with other migrants from the same place of origin. For migrant laborers entering into the same destination area, their interest in changing their hukou and city integration levels decrease with the migration distance. Therefore, a longer distance between their place of origin and destination will lead to a larger cultural gap, greater pressure from left-behind family members, lower levels of psychological identification, and lower levels of city integration (Carpentier and Sablonnière 2013; Wang et al. 2015). As the sense of happiness among migrants who have their own houses is generally higher than that of house-renting migrants, enhanced city integration can help renters increase their sense of happiness more rapidly than those who own their own houses among migrants who have moved long distances. However, there is no significant difference among migrants who have moved a shorter distance. Therefore, Hypothesis 3 is as follows:

Hypothesis 3 With the increase of migration distance, city integration has a more prominent effect on the enhancement of renters' sense of happiness.

\section{Data and variables \\ Data}

The main dataset used in this study is the 2012 Social Integration and Mental Health Special Survey Data from the Migrants Population Dynamic Monitoring Survey. It has been conducted annually by the Migrant Population Service Center, National Health and Family Planning Commission since 2009. Using the PPS sampling method, it covers 31 provinces and the Xinjiang Production and Construction Corps. The respondents are 15-60 year-old migrants who migrated from other cities at least a month ago and have not acquired a hukou in the survey area. In the end, our sample contains 158,556 effective observations, including 133,935 rural migrant workers and 24,621 migrants from urban areas. We do not make a distinction between them in this paper.

\section{Variables setting}

The key independent variable in our study is city integration. Since there is no standard definition of city integration (Spoonley et al. 2005), we refer to Yang's (2015) definition of a migrant population's city integration which consists of cultural integration, social and economic integration, and psychological identification. For preciseness, we follow Qin and Chen (2014) and further define sub-indices in each aspect of city integration using fuzzy set theory (Zadeh 1965) to construct a multi-dimensional city integration index. The fuzzy set theory does not absolutely confirm nor negate a thing but considers the existence of ambiguity in 
decision-making so that all the possible factors that affect the subjective feelings of the respondents can be taken into account. We employ the membership functions to assign each aspect of city integration and finally get a fuzzy set of the membership index, which can reflect the migrant's city integration level to the greatest extent. The membership functions $f\left(\mathrm{x}_{i}^{r}\right)$ we use are as follows:

$$
f\left(\mathrm{x}_{i}^{r}\right)=\left\{\begin{array}{cl}
0, & \text { if } x_{i}^{r}=\min \left(x_{i}^{r}\right), \\
\left(\mathrm{x}_{\mathrm{i}}^{\mathrm{r}}-\min \left(\mathrm{x}_{\mathrm{i}}^{\mathrm{r}}\right)\right) /\left(\max \left(\mathrm{x}_{\mathrm{i}}^{\mathrm{r}}\right)-\min \left(\mathrm{x}_{\mathrm{i}}^{\mathrm{r}}\right)\right), & \text { if } x_{i}^{r} \in\left\{\min \left(x_{i}^{r}\right), \max \left(x_{i}^{r}\right)\right\}, \\
1, & \text { if } x_{i}^{r}=\max \left(x_{i}^{r}\right) .
\end{array}\right.
$$

As shown in Equation (1), $f\left(\mathrm{x}_{i}^{r}\right)$ is a set of membership functions, and $\mathrm{x}_{i}^{r}$ is the $r$ th sub index of the $i$ th aspect of city integration. When $\mathrm{x}_{i}^{r}$ is the maximum value, $f\left(\mathrm{x}_{i}^{r}\right)$

Table 1 Comparisons of each city integration sub-index between heterogeneous migrants

\begin{tabular}{|c|c|c|c|c|c|}
\hline City Integration & Sub-index & & Value & $\begin{array}{l}\text { Migrants- } \\
\text { Homeowners }\end{array}$ & $\begin{array}{l}\text { Migrants- } \\
\text { Renters }\end{array}$ \\
\hline \multirow[t]{6}{*}{ Cultural Integration } & \multirow[t]{2}{*}{ Participate in community sports activities } & No & 0 & $67.31 \%$ & $74.08 \%$ \\
\hline & & Yes & 1 & $32.69 \%$ & $25.92 \%$ \\
\hline & \multirow[t]{2}{*}{ Participate in social public welfare activities } & No & 0 & $61.12 \%$ & $72.01 \%$ \\
\hline & & Yes & 1 & $38.88 \%$ & $27.99 \%$ \\
\hline & \multirow[t]{2}{*}{ Read and learn during leisure time } & No & 0 & $46.11 \%$ & $58.66 \%$ \\
\hline & & Yes & 1 & $53.89 \%$ & $41.34 \%$ \\
\hline \multirow{6}{*}{$\begin{array}{l}\text { Social and } \\
\text { Economic } \\
\text { Integration }\end{array}$} & \multirow[t]{2}{*}{ Communicate most in leisure time with... } & others & 0 & $53.78 \%$ & $75.41 \%$ \\
\hline & & $\begin{array}{l}\text { local } \\
\text { residents }\end{array}$ & 1 & $46.22 \%$ & $24.59 \%$ \\
\hline & \multirow{2}{*}{$\begin{array}{l}\text { Children must pay an entrance fee to } \\
\text { attend a local school }\end{array}$} & Yes & 0 & $92.31 \%$ & $95.3 \%$ \\
\hline & & No & 1 & $7.69 \%$ & $4.7 \%$ \\
\hline & \multirow[t]{2}{*}{ Have medical insurance } & No & 0 & $70.68 \%$ & $82.84 \%$ \\
\hline & & Yes & 1 & $29.32 \%$ & $17.16 \%$ \\
\hline \multirow[t]{12}{*}{$\begin{array}{l}\text { Psychological } \\
\text { Identification }\end{array}$} & \multirow[t]{4}{*}{$\begin{array}{l}\text { I am willing to integrate into and become } \\
\text { a member of the community }\end{array}$} & $\begin{array}{l}\text { Entirely } \\
\text { disagree }\end{array}$ & 1 & $0.75 \%$ & $1.04 \%$ \\
\hline & & disagree & 2 & $1.37 \%$ & $5.57 \%$ \\
\hline & & $\begin{array}{l}\text { Basically } \\
\text { agree }\end{array}$ & 3 & $34.88 \%$ & $50.50 \%$ \\
\hline & & $\begin{array}{l}\text { Entirely } \\
\text { agree }\end{array}$ & 4 & $63.01 \%$ & $42.89 \%$ \\
\hline & \multirow[t]{4}{*}{$\begin{array}{l}\text { I think the locals are willing to accept me } \\
\text { as a part of their community }\end{array}$} & $\begin{array}{l}\text { Entirely } \\
\text { disagree }\end{array}$ & 1 & $0.84 \%$ & $1.15 \%$ \\
\hline & & disagree & 2 & $2.11 \%$ & $6.86 \%$ \\
\hline & & $\begin{array}{l}\text { Basically } \\
\text { agree }\end{array}$ & 3 & $40.93 \%$ & $56.44 \%$ \\
\hline & & $\begin{array}{l}\text { Entirely } \\
\text { agree }\end{array}$ & 4 & $56.13 \%$ & $35.56 \%$ \\
\hline & \multirow[t]{4}{*}{$\begin{array}{l}\text { I feel that the locals are always } \\
\text { contemptuous of migrants }\end{array}$} & $\begin{array}{l}\text { Entirely } \\
\text { agree }\end{array}$ & 1 & $4.14 \%$ & $4.66 \%$ \\
\hline & & $\begin{array}{l}\text { Basically } \\
\text { agree }\end{array}$ & 2 & $12.84 \%$ & $19.33 \%$ \\
\hline & & disagree & 3 & $48.63 \%$ & $50.51 \%$ \\
\hline & & $\begin{array}{l}\text { Entirely } \\
\text { disagree }\end{array}$ & 4 & $34.39 \%$ & $25.50 \%$ \\
\hline
\end{tabular}


equals to 1 ; when $\mathrm{x}_{i}^{r}$ is the minimum value, $f\left(\mathrm{x}_{i}^{r}\right)$ equals to 0 ; when $\mathrm{x}_{i}^{r}$ is between the minimum value and the maximum value, $f\left(\mathrm{x}_{i}^{r}\right)$ is standardized by the foundation $\left(x_{i}^{r}-\right.$ $\left.\min \left(x_{i}^{r}\right)\right) /\left(\max \left(x_{i}^{r}\right)-\min \left(x_{i}^{r}\right)\right)$. Eventually, we get a series of discrete membership degrees. In order to get a comprehensive membership index for each aspect of city integration, we calculate the weighted arithmetic average for all sub-indices of each aspect and eventually the variable-city integration is obtained (Lelli 2001).

Table 1 reports the selection and distribution of sub-indicators in three aspects of city integration. First, there are three sub-indicators to reflect the level of cultural integration-whether the migrant participates in community sports activities, whether he/she participates in social public welfare activities, and whether he/she reads and learns during leisure time. A "yes" answer is defined as 1, representing good cultural integration; and a "no" answer is defined as 0 , representing that it is hard for this migrant to integrate into their new place of residence. Second, the social and economic integration level includes whether or not the migrant communicates most with local residents during their leisure time, whether his/her children need to pay school entrance fees ${ }^{1}$ and whether he/she has medical insurance. If the respondent is in more frequent contact with local residents during leisure time, does not have to pay school fees and medical insurance is secured, the degree of his/her city integration is higher and so each of these answers is assigned 1. Third, the psychological integration level is evaluated through three self-rated questions from the survey database, from the perspective of subjective integration willingness and objective integration environment: I am willing to integrate into and become a member of the community; I feel that the locals are willing to accept me as a part of them; and I feel that the locals are always deeply scornful of strangers. Self-rated answers consist of four dimensions: completely disagree, disagree, basically agree and completely agree, and 1-4 is assigned respectively according to the integration level from low to high. Table 1 also illustrates the proportion of responses to different questions in the different sub-indices of city integration under different living conditions. ${ }^{2}$ It shows that homeowners perform better on the city integration sub-indices than renter migrants. Table $2^{3}$ reports the mean value of city integration and each aspect of city integration among migrants with different homeownership patterns. Renter migrants perform worse than homeowners but the gap is not that great. It reveals that there is no significant difference between city integration and various homeownership. Therefore, we exclude the possible correlation between city integration and homeownership.

A sense of happiness is the key dependent variable in our regressions. This variable is the answer from the self-rated question "Compared with your place of origin, do you feel happier currently?" There are five ranks of sense of happiness: very unhappy, unhappy, neutral, happy, very happy.

In addition, based on the theory of happiness economics, we further control the following individual-level variables: gender, marital status, age, the square of age,

Table 2 Comparison of mean value of city integration among heterogeneous migrants

\begin{tabular}{lllll}
\hline Average value & Integration & Integration- culture & Integration- society & Integration- identity \\
\hline Migrants-Homeowners & 0.59 & 0.42 & 0.56 & 0.81 \\
Migrants-Renters & 0.50 & 0.32 & 0.46 & 0.73 \\
\hline
\end{tabular}


education year, children's information, and family monthly income (Knight et al. 2009; $\mathrm{Li}$ et al. 2011). We use the "year of education" method, one of the measures of human capital, to set up the education year variable (Barro 1990). We then define 3 years of education as illiteracy, 6 years of education as primary school level, 9 years as the junior high school level, 12 years as the high school level, 16 years as the college degree level, and 18 years of education as the postgraduate and above level. As well, we use the logarithm of the family monthly income. Furthermore, we control city-level variables following Lu et al. (2017) which includes GDP per capita and resident population. Also, we use the logarithm for these two city-level control variables.

In order to investigate the cooperative relationship between housing status, city integration and the sense of happiness of "ascending" and "descending" migrants, we use 2012 province-level per capita GDP data from the National Statistics Bureau to measure the economic development of the migration destination regions and the regions of origin, and then divide the migration directions into those with an "ascending" migration experience and those with a "falling" migration experience. If the GDP per capita in the province of origin is lower than that in the province where the migrant is currently living, it is regarded as an "ascending" migration experience. If the GDP per capita in the province of origin is higher than that in the current province of residence, it is regarded as a "falling" migration process. To explore the cooperative effects among people who have migrated different distances, we divide all the migrants into two subsamples: The first one is people who have migrated between two different provinces and the second one is people who have migrated within a province. The details of the variables are shown in Tables 3 and 4. Table 3 illustrates the distribution of different types of migrants' sense of happiness. Generally, most renters and homeowner migrants feel happy but the proportion of renters who are very unhappy, unhappy and general is more than that of homeowners. Compared with homeowners, renter migrants have a lower sense of happiness. In addition, variables used in this paper are listed in Table 4.

\section{Model setting}

Since the dependent variable "Happiness" is in the form of discrete ordinal data (order data), using traditional OLS regression will hurt the accuracy of the results. Thus, we use the Ordinal Logistic Regression (Ologit) to deal with order data. We further use the city-fixed effect model to avoid possible errors caused by missing variables (see Table 5 for details). The model is as follows.

Happiness $_{i}=G\left(\beta_{1}\right.$ Integration $_{i}+\beta_{2}$ Buyhouse $_{i}+\beta_{3}$ Integration $_{i} \times$ Buyhouse $\left._{i}+\gamma X_{i}+\phi X_{j}+\varepsilon_{i}\right)$

Table 3 Distribution of migrants' sense of happiness

\begin{tabular}{lllllll}
\hline & Very unhappy & Unhappy & Neutral & Happy & Very happy & $N$ \\
\hline All migrants & $0.18 \%$ & $1.43 \%$ & $35.86 \%$ & $47.85 \%$ & $14.68 \%$ & 158,333 \\
Migrants-Homeowners & $0.10 \%$ & $0.55 \%$ & $18.98 \%$ & $54.27 \%$ & $26.09 \%$ & 19,521 \\
Migrants-Renters & $0.19 \%$ & $1.55 \%$ & $38.24 \%$ & $46.95 \%$ & $13.08 \%$ & 138,812 \\
\hline
\end{tabular}


Table 4 Explanation of main variables and descriptive statistics

\begin{tabular}{|c|c|c|c|c|c|c|c|}
\hline Category & Variable & Definition & $N$ & Mean & SD & Min & Max \\
\hline $\begin{array}{l}\text { Dependent } \\
\text { variable }\end{array}$ & Happiness & $\begin{array}{l}\text { Very unhappy }=1 \text {, unhappy }=2 \text {, neutral }=3 \text {, } \\
\text { happy }=4 \text {, very happy }=5 .\end{array}$ & 158,333 & 3.75 & 0.72 & 1 & 5 \\
\hline \multirow{2}{*}{$\begin{array}{l}\text { Independent } \\
\text { variable }\end{array}$} & Integration & Details are listed in Table 1. & 158,556 & 0.51 & 0.16 & 0 & 1 \\
\hline & Buyhouse & $\begin{array}{l}\text { Home ownership dummy: homeowner }=1 \text {, } \\
\text { renter }=0 \text {. }\end{array}$ & 158,556 & 0.12 & 0.33 & 0 & 1 \\
\hline \multirow[t]{2}{*}{$\begin{array}{l}\text { Instrumental } \\
\text { variable }\end{array}$} & Unemprate & $\begin{array}{l}\text { Urban unemployment rate in the provinces } \\
\text { where the hukou is located. }\end{array}$ & 158,485 & 3.47 & 0.48 & 1.27 & 4.23 \\
\hline & Pulimit & $\begin{array}{l}\text { Dummy for property ownership restriction } \\
\text { policy in effect in the region. If there is a } \\
\text { purchase restriction policy }=1, n o=0 \text {. }\end{array}$ & 158,556 & 0.57 & 050 & 0 & 1 \\
\hline \multirow{7}{*}{$\begin{array}{l}\text { Control } \\
\text { variable- } X_{i}\end{array}$} & Gender & Gender dummy: female $=1$, male $=0$. & 158,556 & 0.47 & 0.50 & 0 & 1 \\
\hline & Marriage & $\begin{array}{l}\text { Marriage dummy: } \text { married }=1 \text {, unmarried }= \\
0 .\end{array}$ & 158,556 & 0.78 & 0.41 & 0 & 1 \\
\hline & Age & Age. & 158,556 & 33.67 & 9.31 & 15 & 60 \\
\hline & Age_sq & Age's square. & 158,556 & 1220.40 & 657.22 & 225 & 3600 \\
\hline & Eduyear & Education year. & 158,556 & 9.75 & 2.82 & 3 & 18 \\
\hline & Havekid & $\begin{array}{l}\text { Child dummy: } \\
\text { have kids }=1, \text { no }=0 \text {. }\end{array}$ & 158,556 & 0.72 & 0.45 & 0 & 1 \\
\hline & Income & $\begin{array}{l}\text { The logarithm of a family's monthly } \\
\text { income. }\end{array}$ & 158,556 & 8.21 & 1.01 & 0 & 11.50 \\
\hline \multirow[t]{3}{*}{$\begin{array}{l}\text { Control } \\
\text { variable- } X_{j}\end{array}$} & GDP & $\begin{array}{l}\text { The logarithm of GDP per capita in } \\
\text { destination cities. }\end{array}$ & 151,249 & 10.95 & 0.54 & 8.86 & 12.12 \\
\hline & Population & $\begin{array}{l}\text { The logarithm of resident population in } \\
\text { destination cities. }\end{array}$ & 149,891 & 6.38 & 1.02 & 2.92 & 7.99 \\
\hline & City FE & City dummy. & & & & & \\
\hline
\end{tabular}

$X_{i}$ refers to individual-level control variables and $X_{j}$ refers to the city-level control variables. Our attention is on the coefficient of the interaction between city integration and housing status, i.e., $\beta_{3}$. If $\beta_{3}$ is significantly negative, Hypothesis 1 is proved. If the absolute value of $\beta_{3}$ in the "ascending" experience subsample is larger than that in the "falling" experience subsample, then Hypothesis 2 is supported. Similarly, Hypothesis 3 is supported if $\beta_{3}$ is negative both in the large-scale migration group and the small-scale migration group but its absolute value in the former is larger than that in the latter. However, since the total effect of the interaction item involves not only its coefficient but also the city integration coefficient and its median value in each subsample, we should consider them all and make a clearer comparison.

\section{Empirical analysis}

The results of the Ologit regression test of the full sample are reported in Table 5. Columns (1) and (2) show the coefficients of the main regression. Regression results controlled with the city-fixed effect are reported in column (1) and results not controlled with the city-fixed effect but with city-level variables are reported in column (2). As the estimation coefficients of the Ologit regression cannot reflect the degree of influence of the explaining variables on the explained variables, as would be the case in an OLS regression, we can only judge the general relationship between explaining variables and explained variables by estimating the coefficients' direction and statistical significance. Therefore, we calculate the 
Table $\mathbf{5}$ Ologit results of full sample migrants

\begin{tabular}{|c|c|c|c|c|c|c|c|}
\hline & \multicolumn{2}{|c|}{ Regression coefficient } & \multicolumn{5}{|c|}{ Marginal effect } \\
\hline & (1) & (2) & (3) & (4) & (5) & (6) & (7) \\
\hline & & & $\begin{array}{l}\text { Happy = } 1 \\
\text { (Very } \\
\text { unhappy) }\end{array}$ & $\begin{array}{l}\text { Happy }=2 \\
\text { (Unhappy) }\end{array}$ & $\begin{array}{l}\text { Happy = } \\
3 \\
\text { (Neutral) }\end{array}$ & $\begin{array}{l}\text { Happy= } \\
4 \\
\text { (Hарpy) }\end{array}$ & $\begin{array}{l}\text { Happy }=5 \\
\text { (Very } \\
\text { happy) }\end{array}$ \\
\hline \multirow[t]{2}{*}{ Integration } & $3.287^{* * *}$ & $3.413^{* * *}$ & $-0.006^{* * *}$ & $-0.049^{* * *}$ & $-\overline{0.688^{* * *}}$ & $0.344^{* * *}$ & $0.399^{* * *}$ \\
\hline & $(87.584)$ & $(92.449)$ & $(-15.858)$ & $(-41.879)$ & $\begin{array}{l}(- \\
101.262)\end{array}$ & $(88.457)$ & (86.069) \\
\hline \multirow[t]{2}{*}{ Buyhouse } & $0.694^{* * *}$ & $0.903^{* * *}$ & $-0.002^{* * *}$ & $-0.013^{* * *}$ & $-\overline{0.182^{* * *}}$ & $0.091^{* * *}$ & $0.106^{* * *}$ \\
\hline & (12.283) & (15.153) & $(-11.028)$ & $(-14.414)$ & $(-15.231)$ & $(15.301)$ & $(15.054)$ \\
\hline \multirow[t]{2}{*}{ Integration $\times$ Buyhouse } & $-0.297^{* * *}$ & $-0.438^{* * *}$ & $0.001^{* * *}$ & $0.006^{* * *}$ & $0.088^{* * *}$ & $-0.044^{* * *}$ & $-0.051^{* * *}$ \\
\hline & $(-3.200)$ & $(-4.472)$ & $(4.307)$ & $(4.451)$ & $(4.478)$ & $(-4.491)$ & $(-4.463)$ \\
\hline \multirow[t]{2}{*}{ Age } & $-0.023^{* * *}$ & $-0.023^{* * *}$ & $0.000^{* * *}$ & $0.000^{* * *}$ & $0.005^{* * *}$ & $-0.002^{* * *}$ & $-0.003^{* * *}$ \\
\hline & $(-5.598)$ & $(-5.386)$ & (5.108) & $(5.351)$ & (5.388) & $(-5.385)$ & $(-5.385)$ \\
\hline \multirow[t]{2}{*}{ Age_sq } & $0.000^{* * *}$ & $0.000^{* * *}$ & $-0.000^{* * *}$ & $-0.000^{* * *}$ & $\overline{-} .000^{* * *}$ & $0.000^{* * *}$ & $0.000^{* * *}$ \\
\hline & $(5.737)$ & $(5.726)$ & $(-5.395)$ & $(-5.684)$ & $(-5.728)$ & $(5.725)$ & $(5.725)$ \\
\hline \multirow[t]{2}{*}{ Eduyear } & $-0.042^{* * *}$ & $-0.052^{* * *}$ & $0.000^{* * *}$ & $0.001^{* * *}$ & $0.011^{* * *}$ & $-0.005^{* * *}$ & $-0.006^{* * *}$ \\
\hline & $(-20.905)$ & $(-25.259)$ & $(13.572)$ & (22.238) & $(25.401)$ & $(-25.099)$ & $(-25.149)$ \\
\hline \multirow[t]{2}{*}{ Gender } & $0.112^{* * *}$ & $0.106^{* * *}$ & $-0.000^{* * *}$ & $-0.002^{* * *}$ & $-\overline{0.021^{* * *}}$ & $0.011^{* * *}$ & $0.012^{* * *}$ \\
\hline & $(11.278)$ & $(10.344)$ & $(-8.701)$ & $(-10.101)$ & $(-10.354)$ & (10.334) & (10.336) \\
\hline \multirow[t]{2}{*}{ Marriage } & $0.237^{* * *}$ & $0.265^{* * *}$ & $-0.000^{* * *}$ & $-0.004^{* * *}$ & $-0.053^{* * *}$ & $0.027^{* * *}$ & $0.031^{* * *}$ \\
\hline & (9.639) & $(10.341)$ & $(-8.700)$ & $(-10.100)$ & $(-10.354)$ & $(10.343)$ & (10.328) \\
\hline \multirow[t]{2}{*}{ Havekid } & $0.167^{* * *}$ & $0.149^{* * *}$ & $-0.000^{* * *}$ & $-0.002^{* * *}$ & $\overline{0} .030^{* * *}$ & $0.015^{* * *}$ & $0.017^{* * *}$ \\
\hline & (7.645) & $(6.516)$ & $(-6.040)$ & $(-6.455)$ & $(-6.519)$ & (6.514) & $(6.515)$ \\
\hline \multirow[t]{2}{*}{ Income } & $0.109^{* * *}$ & $0.088^{* * *}$ & $-0.000^{* * *}$ & $-0.001^{* * *}$ & $-0.018^{* * *}$ & $0.009^{* * *}$ & $0.010^{* * *}$ \\
\hline & (19.606) & (15.392) & $(-11.116)$ & $(-14.625)$ & $(-15.432)$ & (15.384) & (15.356) \\
\hline \multirow[t]{2}{*}{ GDP } & & $0.048^{* * *}$ & $-0.000^{* * *}$ & $-0.001^{* * *}$ & $-\overline{0.010^{* * *}}$ & $0.005^{* * *}$ & $0.006^{* * *}$ \\
\hline & & $(4.874)$ & $(-4.665)$ & $(-4.848)$ & $(-4.875)$ & $(4.873)$ & $(4.873)$ \\
\hline \multirow[t]{2}{*}{ Population } & & $-0.070^{* * *}$ & $0.000^{* * *}$ & $0.001^{* * *}$ & $0.014^{* * *}$ & $-0.007^{* * *}$ & $-0.008^{* * *}$ \\
\hline & & $(-11.879)$ & $(9.557)$ & (11.516) & (11.894) & $(-11.864)$ & $(-11.865)$ \\
\hline City FE & YES & NO & NO & NO & NO & NO & NO \\
\hline$N$ & 158,333 & 144,720 & & & & & \\
\hline LR Chi ${ }^{2}$ & $23,245.16^{* * *}$ & $14,761.21^{* * *}$ & & & & & \\
\hline Pseudo $R^{2}$ & 0.0683 & 0.0475 & & & & & \\
\hline
\end{tabular}

Notes. Regression results controlled with the city-fixed effect are reported in column (1) and results not controlled with the city-fixed effect but with city-level variables are reported in column (2). Columns (3)-(7) are the marginal effects of the explaining variables on "Happiness" respectively. $z$ statistics are in parentheses. ${ }^{*},{ }^{* *}$, and ${ }^{* * *}$ represent the significance level at $10 \%, 5 \%$ and $1 \%$ respectively

marginal effects of the explaining variables on "Happiness" respectively which are reported in columns (3)-(7). Table 5 shows that buying houses and improving migrants' city integration can both enhance their sense of happiness. However, the interaction item between buying houses and city integration is negative, which implies that a negative synergistic effect on the sense of happiness exists. 
The renters' sense of happiness will be enhanced more than the homeowners with an increase in their city integration level.

The marginal effect reflects the changes in the corresponding probability of every value of "Happiness" with one unit of change of the independent variables. We use the traditional marginal effect calculation method which calculates the mean value of all samples and then calculates the marginal effect in every mean value point. The marginal effect results of the variable "Buyhouse" in Table 5 shows that when all the independent variables are in the mean value and house purchasing increases by $1 \%$, the probability of migrants feeling "Very unhappy" is significantly reduced by $0.2 \%$, the probability of "Unhappy" is significantly reduced by $1.3 \%$, the probability of "Neutral" is reduced by $18.2 \%$, the probability of "Happy" is increased by $9.1 \%$ and the probability of "Very happy" is increase by $10.6 \%$. At the same time, when all the independent variables are in the mean value and city integration is promoted by 1 unit, the probability of "Very unhappy," "Unhappy" and "Neutral" decreases by $0.6 \%, 4.9 \%$ and $68.8 \%$ respectively, and the probability of "Happy" and "Very happy" significantly increase by $34.4 \%$ and $39.9 \%$ respectively. House purchasing and higher city integration can indeed enhance the sense of happiness of migrants. Similarly, the marginal effect results of the interaction term show that when all the independent variables are in the mean value and the city integration level increases by 1 unit, the probability of renter migrants feeling "Very unhappy" decreases by $0.1 \%$, the probability of "Unhappy" decreases by $0.6 \%$, the probability of "Neutral" decreases by $8.8 \%$, the probability of "Happy" increases by $4.4 \%$ and the probability of "Very happy" increases by $5.1 \%$. It shows that when the renter migrants' city integration is secured and improved, their sense of happiness is significantly enhanced. The above validates Hypothesis 1 and verifies the main regression results in Table 5 .

Control variables are also significant at the $1 \%$ level. There is a U-shape relationship between age and happiness; education and happiness have a negative correlation; females, married migrants, migrants who have children and high incomes always have a higher sense of happiness. In addition, the city-level control variables satisfy both the economic theory that there is a positive correlation between GDP per capita and happiness and a negative correlation between the number of people with hukou and the sense of happiness of migrants.

Table 6 shows the impacts of the heterogeneity of migration direction and distance on the relationship between housing purchases, city integration and sense of happiness. First, migrants are divided into two subsamples according to the different migration directions: One is the population that migrated from less developed areas to developed areas and the other is the population that migrated from developed areas to underdeveloped areas. The empirical results of the former subsample are listed in column (1) and those of the latter are listed in column (2). The coefficient of the interaction item "Integration $\times$ Buyhouse" is significant and negative at the level of $1 \%$ in the former subsample and it is negative but not significant in the latter one. It is obvious that for the migrants who moved from underdeveloped areas to developed areas there is a significant negative synergy effect of housing purchase and city integration on their sense of happiness. The effect of city integration on the renters' sense of happiness is greater than that on homeowners. However, this negative synergy effect does not exist in the group that migrated from developed areas to less developed areas. Thus, Hypothesis 2 is supported. 
Table 6 Ologit results of heterogeneous migrants

\begin{tabular}{|c|c|c|c|c|}
\hline & \multicolumn{2}{|c|}{ Migration direction heterogeneity } & \multicolumn{2}{|c|}{ Migration distance heterogeneity } \\
\hline & $\begin{array}{l}\text { (1) migration with an } \\
\text { "ascending" experience }\end{array}$ & $\begin{array}{l}\text { (2) migration with a } \\
\text { "falling" experience }\end{array}$ & $\begin{array}{l}\text { (3) migration over } \\
\text { a longer distance }\end{array}$ & $\begin{array}{l}\text { (4) migration over } \\
\text { a shorter distance }\end{array}$ \\
\hline \multirow[t]{2}{*}{ Integration } & $3.297^{* * *}$ & $3.475^{* * *}$ & $3.334^{* * *}$ & $3.343^{* * *}$ \\
\hline & $(57.836)$ & (30.669) & $(65.651)$ & $(61.034)$ \\
\hline \multirow[t]{2}{*}{ Buyhouse } & $1.100^{* * *}$ & $0.653^{* * *}$ & $0.996^{* * *}$ & $0.764^{* * *}$ \\
\hline & $(10.925)$ & $(3.424)$ & $(11.194)$ & $(9.433)$ \\
\hline \multirow[t]{2}{*}{ Integration $\times$ Buyhouse } & $-0.699^{* * *}$ & -0.133 & $-0.571^{* * *}$ & $-0.260^{* *}$ \\
\hline & $(-4.228)$ & $(-0.419)$ & $(-3.900)$ & $(-1.963)$ \\
\hline \multirow[t]{2}{*}{ Age } & $-0.018^{* * *}$ & $-0.023^{*}$ & $-0.017^{* * *}$ & $-0.032^{* * *}$ \\
\hline & $(-2.655)$ & $(-1.768)$ & $(-2.854)$ & $(-4.855)$ \\
\hline \multirow[t]{2}{*}{ Age_sq } & $0.000^{* * *}$ & $0.000^{*}$ & $0.000^{* * *}$ & $0.000^{* * *}$ \\
\hline & (3.593) & $(1.769)$ & (3.659) & $(4.482)$ \\
\hline \multirow[t]{2}{*}{ Eduyear } & $-0.063^{* * *}$ & $-0.045^{* * *}$ & $-0.060^{* * *}$ & $-0.044^{* * *}$ \\
\hline & $(-20.076)$ & $(-7.183)$ & $(-21.556)$ & $(-14.128)$ \\
\hline \multirow[t]{2}{*}{ Gender } & $0.103^{* * *}$ & $0.117^{* * *}$ & $0.104^{* * *}$ & $0.095^{* * *}$ \\
\hline & $(6.651)$ & (3.712) & $(7.445)$ & (6.179) \\
\hline \multirow[t]{2}{*}{ Marriage } & $0.265^{* * *}$ & $0.232^{* * *}$ & $0.257^{* * *}$ & $0.306^{* * *}$ \\
\hline & $(7.042)$ & (2.991) & (7.605) & $(7.764)$ \\
\hline \multirow[t]{2}{*}{ Havekid } & $0.136^{* * *}$ & $0.161^{* *}$ & $0.145^{* * *}$ & $0.135^{* * *}$ \\
\hline & $(4.040)$ & (2.388) & $(4.825)$ & (3.778) \\
\hline \multirow[t]{2}{*}{ Income } & $0.113^{* * *}$ & $0.068^{* * *}$ & $0.100^{* * *}$ & $0.091^{* * *}$ \\
\hline & (11.958) & $(4.574)$ & $(12.562)$ & $(10.782)$ \\
\hline \multirow[t]{2}{*}{ GDP } & $0.067^{* * *}$ & $0.051^{*}$ & $0.064^{* * *}$ & $0.085^{* * *}$ \\
\hline & (3.297) & (1.859) & $(4.276)$ & (6.118) \\
\hline \multirow[t]{2}{*}{ Population } & $-0.069^{* * *}$ & 0.027 & $-0.048^{* * *}$ & $-0.053^{* * *}$ \\
\hline & $(-7.344)$ & $(1.376)$ & $(-5.919)$ & $(-5.634)$ \\
\hline $\mathrm{Chi}^{2}$ & $4.38^{* *}$ & & $3.81^{*}$ & \\
\hline N & 64,141 & 15,956 & 80,097 & 64,623 \\
\hline LR Chi ${ }^{2}$ & $6133.86^{* * *}$ & $1525.02^{* * *}$ & $7600.53^{* * *}$ & $6477.23^{* * *}$ \\
\hline Pseudo $R^{2}$ & 0.0446 & 0.0455 & 0.0444 & 0.0467 \\
\hline
\end{tabular}

Notes. The sample in column (1) is the population who migrated from a region with a lower GDP per capita to a region with a higher GDP per capita; column (2) is the population who migrated from a region with a higher GDP per capita to a region with a lower GDP per capita. The sample in column (3) is migrants who moved across two different provinces; column (4) is migrants who moved within a province. $z$ statistics are in parentheses. ${ }^{*},{ }^{*}$, and ${ }^{* *}$ represent the significance level at $10 \%, 5 \%$ and $1 \%$ respectively

Compared with less developed regions, developed regions have higher levels of economic development, more employment opportunities and more quality educational and medical resources, which attract many skilled people. Therefore, competition is more intense in the developed regions and it is harder for unskilled or uneducated migrants, especially for renter migrants to integrate. For migrants who rent housing, city integration and sense of happiness are both at such a low level that the space for improvement is relatively large and increasing city integration can enhance their sense of happiness more significantly. By contrast, city integration and sense of happiness for migrants who moved from undeveloped regions and already own their houses are both higher so that the improvement effect is not prominent. 
Second, columns (3) and (4) report the empirical results of two subsamples with different migration distances. Column (3) shows the trans-provincial subsample. The coefficient of the interaction item "Integration $\times$ Buyhouse" is -0.571 , which is significant and negative at the $1 \%$ level. Column (4) shows the results for the migrants who moved within a province. The coefficient of the interaction item is -0.260 , and it is significant and negative at the $5 \%$ level. The coefficient in the first interaction is larger than that in the second. The difference between the two coefficients is significant and has passed the inter-group coefficient test. After calculation, the total effect of the interaction term in the short migration distance subsample is -0.274 and in the long migration distance subsample is -0.135 . Therefore, the negative synergy effect in the migrant population who moved across provinces is stronger than for people who migrated within a province. Hypothesis 3 is supported. The further the migrants moved, the greater the negative synergy is.

Possible reasons for this are as follows. Firstly, from an individual psychological perspective, a long distance between the migrants' destination and hometown contributes to a lack of sense of security and thus more difficulty in integrating into local society. Secondly, from a city integration perspective, the difficulty in city integration for migrants whose hometowns are far away comes from differences in culture, customs and habits, and unfamiliarity with the social networks in their new place of residence. Therefore, people who have migrated further have lower levels of city integration, they choose to rent houses in new unfamiliar places and thus they feel unhappy. If their integration into the city is improved, their sense of happiness can be rapidly raised. Homeowners' city integration and sense of happiness are both higher, therefore the increase in levels of sense of happiness with the improvement of city integration is smaller.

In addition, in each migration heterogeneity subsample, owning a house and city integration both have a significant and positive impact (1\%) on the sense of happiness, and the results for the control variables are also consistent with our findings in Table 5.

\section{Robustness tests}

\section{Adjustments to the subsamples' definitions}

As mentioned above, migration directions are distinguished by province-level GDP per capita which can reflect different regional economic development levels. In reality, people do not contrast economic development differences between two places by accurately comparing the per capita GDP but through their own perceptions. For example, it is generally accepted that the middle and western regions of China have relatively low economic development levels and the eastern part of China is more developed and has more employment opportunities. Consequently, considering the robustness of our empirical results, we then divide the developed regions and underdeveloped regions using a new division standard from China's National Economic and Social Development statistical database. People whose household registration is in the middle or western part of China and current place of residence is in the eastern part of China are regarded as migrants who have migrated from underdeveloped regions to developed regions, and people whose places of origin are in the east and destination places located in the middle or west are regarded as migrants who have migrated from developed regions to less developed regions. Then we retest Hypothesis 2. As well, we further minimize the sample to 
Table 7 Ologit results of heterogeneous migrants under a new definition

\begin{tabular}{|c|c|c|c|c|}
\hline & \multicolumn{2}{|c|}{ Migration direction heterogeneity } & \multicolumn{2}{|c|}{ Migration distance heterogeneity } \\
\hline & $\begin{array}{l}\text { (1) migration with an } \\
\text { "ascending" experience }\end{array}$ & $\begin{array}{l}\text { (2) migration with a } \\
\text { "falling" experience }\end{array}$ & $\begin{array}{l}\text { (3) migration over } \\
\text { a longer distance }\end{array}$ & $\begin{array}{l}\text { (4) migration over } \\
\text { a shorter distance }\end{array}$ \\
\hline \multirow[t]{2}{*}{ Integration } & $3.221^{* * * *}$ & $3.346^{* * *}$ & $3.213^{* * *}$ & $3.513^{* * *}$ \\
\hline & $(44.900)$ & $(16.325)$ & (49.553) & $(42.843)$ \\
\hline \multirow[t]{2}{*}{ Buyhouse } & $1.228^{* * *}$ & 0.507 & $1.022^{* * *}$ & $0.956^{* * *}$ \\
\hline & $(8.644)$ & $(1.602)$ & (8.903) & $(6.784)$ \\
\hline \multirow[t]{2}{*}{ Integration $\times$ Buyhouse } & $-0.940^{* * *}$ & 0.128 & $-0.659^{* * *}$ & $-0.444^{*}$ \\
\hline & $(-4.071)$ & $(0.240)$ & $(-3.491)$ & $(-1.912)$ \\
\hline \multirow[t]{2}{*}{ Age } & -0.010 & $-0.052^{* *}$ & -0.011 & $-0.025^{* * *}$ \\
\hline & $(-1.235)$ & $(-2.234)$ & $(-1.434)$ & $(-2.662)$ \\
\hline \multirow[t]{2}{*}{ Age_sq } & $0.000^{* *}$ & $0.001^{* *}$ & $0.000^{* *}$ & $0.000^{* * *}$ \\
\hline & $(2.211)$ & $(2.036)$ & $(2.057)$ & (3.189) \\
\hline \multirow[t]{2}{*}{ Eduyear } & $-0.070^{* * *}$ & $-0.029^{* *}$ & $-0.058^{* * *}$ & $-0.061^{* * *}$ \\
\hline & $(-17.630)$ & $(-2.567)$ & $(-16.727)$ & $(-13.145)$ \\
\hline \multirow[t]{2}{*}{ Gender } & $0.119^{* * *}$ & $0.133^{* *}$ & $0.113^{* * *}$ & $0.089^{* * *}$ \\
\hline & $(6.160)$ & $(2.349)$ & $(6.402)$ & $(3.917)$ \\
\hline \multirow[t]{2}{*}{ Marriage } & $0.175^{* * *}$ & $0.573^{* * *}$ & $0.248^{* * *}$ & $0.273^{* * *}$ \\
\hline & (3.653) & (4.155) & (5.910) & $(4.788)$ \\
\hline \multirow[t]{2}{*}{ Havekid } & $0.192^{* * * *}$ & -0.067 & $0.149^{* * *}$ & $0.137^{* * *}$ \\
\hline & $(4.435)$ & $(-0.566)$ & $(4.013)$ & $(2.691)$ \\
\hline \multirow[t]{2}{*}{ Income } & $0.148^{* * *}$ & $0.055^{* *}$ & $0.098^{* * *}$ & $0.107^{* * *}$ \\
\hline & (11.495) & $(2.132)$ & (9.731) & (8.208) \\
\hline \multirow[t]{2}{*}{ GDP } & $0.166^{* * *}$ & 0.064 & $0.136^{* * *}$ & -0.018 \\
\hline & $(5.515)$ & $(1.347)$ & $(6.598)$ & $(-0.825)$ \\
\hline \multirow[t]{2}{*}{ Population } & $-0.147^{* * *}$ & $0.106^{* * *}$ & $-0.055^{* * *}$ & $-0.058^{* * *}$ \\
\hline & $(-9.198)$ & (3.268) & $(-5.162)$ & $(-4.461)$ \\
\hline $\mathrm{Chi}^{2}$ & $3.16^{*}$ & & $8.05^{* * *}$ & \\
\hline$N$ & 41,611 & 5014 & 50,072 & 30,025 \\
\hline LR Chi ${ }^{2}$ & $3857.96^{* * *}$ & $476.94^{* * *}$ & $4459.91^{* * *}$ & $3175.71^{* * *}$ \\
\hline Pseudo $R^{2}$ & 0.0433 & 0.0455 & 0.0418 & 0.0493 \\
\hline
\end{tabular}

Notes. The sample in column (1) is the population who migrated from the middle or western part of China to the eastern part of China; column (2) is the population who migrated from the eastern part of China to the middle or western part of China. The sample in column (3) is the migrants who moved between two non-adjacent provinces; column (4) is migrants who moved between two neighboring provinces. $z$ statistics are in parentheses. ${ }^{*},{ }^{* *}$, and ${ }^{* *}$ represent the significance level at $10 \%, 5 \%$ and $1 \%$ respectively

migrants who moved across provinces and divide them into the migrants who moved between two neighboring provinces (migration over a shorter distance) and two non-adjacent provinces (migration over a longer distance). Then we examine the synergistic effect again and retest Hypothesis 3. The robustness test results are indicated in Table 7.

After redefining the migration direction heterogeneity, we find that the interaction item "Integration $\times$ Buyhouse" is not significant in the "falling" migration subsample, but still significant and negative at the $1 \%$ level in the "ascending" migration subsample. Similarly, under the new classification of migration distance, the coefficients of the interaction item in the shorter distance subsample and the longer distance subsample 
are both significant and negative. But both the absolute value and the total effect we calculated in the latter is larger than in the former, which has passed the inter-group coefficient difference test based on the seemingly unrelated regression. Therefore, the robustness test results above are in concert with those using the original classification method.

\section{Advanced solution to the endogeneity problem}

City integration and migrants' sense of happiness interact as both cause and effect. Specifically, people's city integration situations are affected by their own happiness levels. For migrants with a higher sense of happiness, their inner driving force to integrate into new living environments is also stronger. So even if it is hard to integrate into new societies, strong desires can help them positively integrate. Since we focus on the effect of city integration on the sense of happiness of migrants, it is necessary to use the instrumental variables method to further solve this endogeneity problem.

Accordingly, we first follow Lian et al. (2014) and choose the urban unemployment rate of the migrants' hukou-located provinces in 2012 as one of the instrumental variables, i.e., "Unemprate." The data is derived from the China Statistical Yearbook 2013. The reason for choosing the unemployment rate as an instrumental variable is that a high unemployment rate in the region of origin will encourage a migrant to actively integrate into a new living place, otherwise he/she will return to the hometown facing a high risk of unemployment. The urban unemployment rate of the hukou-located area has no relationship with the migrant' sense of happiness but has a strong correlation with his/her degree of city integration, which implies that it is an effective exogenous instrumental variable.

Another instrumental variable, "Pulimit," is whether the migrant's destination in 2012 has a house purchase restriction policy. This policy's implementation prevents migrants from buying their own houses in the place of destination, distinguishes them from local residents and other migrants who have already obtained local hukou, and further raises barriers to integration. Therefore, the house purchase restriction policy affects migrants' sense of happiness by influencing their city integration levels. We speculate that this instrumental variable is negatively correlated with city integration.

Generally, the ordinary two-stage-least-squares regression is often used to solve the endogeneity problem, but it fails when the dependent variable and the independent variable are both ordered variables. Therefore, we try the Conditional Mixed Process (CMP) method, a kind of the two-stage-least-squares methods which is generally received and widely used, to re-estimate all the hypotheses (Roodman 2011). It is noteworthy that the first-stage regression of CMP is used to examine the correlation between instrumental variables and endogenous variables correspondingly and the second stage puts the instrumental variables into the basic model using the simultaneous likelihood estimation method and tests the exogeneity of the endogenous variables through the test parameter atanhrho_12. If atanhrho_12 is significantly different from 0 , this model is proved to have an endogeneity problem and using the CMP estimate method is better than the Ologit. However, if the test parameter does not significantly differ from 0 , the Ologit regression results are useful for reference. The estimated results are reported in Table 8. 
Table 8 CMP regression results

\begin{tabular}{|c|c|c|c|c|c|}
\hline & \multirow{2}{*}{$\begin{array}{l}\text { Full } \\
\text { sample } \\
\text { (1) }\end{array}$} & \multicolumn{2}{|c|}{ Migration direction heterogeneity } & \multicolumn{2}{|c|}{ Migration distance heterogeneity } \\
\hline & & $\begin{array}{l}\text { (2) migration with an } \\
\text { "ascending" } \\
\text { experience }\end{array}$ & $\begin{array}{l}\text { (3) migration with } \\
\text { a "falling" } \\
\text { experience }\end{array}$ & $\begin{array}{l}\text { (4) migration } \\
\text { over a longer } \\
\text { distance }\end{array}$ & $\begin{array}{l}\text { (5) } \\
\text { migration over } \\
\text { a shorter } \\
\text { distance }\end{array}$ \\
\hline \multirow[t]{2}{*}{ Integrationn } & $5.754^{* * *}$ & $6.263^{* * *}$ & $-1.689^{*}$ & $5.225^{* * *}$ & $5.804^{* * *}$ \\
\hline & $(45.710)$ & $(9.534)$ & $(-1.871)$ & (9.058) & $(60.378)$ \\
\hline \multirow[t]{2}{*}{ Buyhouse } & $0.354^{* * *}$ & $0.382^{* *}$ & $0.272^{* * *}$ & $0.470^{* * *}$ & $0.254^{* * *}$ \\
\hline & $(12.279)$ & $(2.540)$ & $(2.770)$ & $(7.601)$ & $(7.493)$ \\
\hline \multirow[t]{2}{*}{ Integration $\times$ Buyhouse } & $-0.153^{* * *}$ & $-0.241^{* *}$ & 0.017 & $-0.266^{* * *}$ & -0.037 \\
\hline & $(-3.685)$ & $(-2.202)$ & $(0.106)$ & $(-3.562)$ & $(-0.687)$ \\
\hline \multirow[t]{2}{*}{ Age } & $-0.009^{* * *}$ & $-0.005^{*}$ & -0.010 & $-0.007^{* *}$ & $-0.011^{* * *}$ \\
\hline & $(-4.669)$ & $(-1.669)$ & $(-1.556)$ & $(-2.284)$ & $(-4.364)$ \\
\hline \multirow[t]{2}{*}{ Age_sq } & $0.000^{* * *}$ & $0.000^{* *}$ & 0.000 & $0.000^{* * *}$ & $0.000^{* * *}$ \\
\hline & (4.939) & $(2.000)$ & $(1.606)$ & $(3.045)$ & $(3.850)$ \\
\hline \multirow[t]{2}{*}{ Eduyear } & $-0.021^{* * *}$ & $-0.022^{* * *}$ & $-0.022^{* * *}$ & $-0.028^{* * *}$ & $-0.016^{* * *}$ \\
\hline & $\begin{array}{l}(- \\
17.339)\end{array}$ & $(-2.598)$ & $(-5.890)$ & $(-9.343)$ & $(-11.490)$ \\
\hline \multirow[t]{2}{*}{ Gender } & $0.045^{* * *}$ & $0.036^{* *}$ & $0.058^{* * *}$ & $0.050^{* * *}$ & $0.038^{* * *}$ \\
\hline & (9.688) & $(2.444)$ & (3.550) & (6.136) & (6.185) \\
\hline \multirow[t]{2}{*}{ Marriage } & $0.105^{* * *}$ & $0.083^{* *}$ & $0.113^{* * *}$ & $0.113^{* * *}$ & $0.119^{* * *}$ \\
\hline & (9.238) & $(2.440)$ & $(2.885)$ & (5.884) & $(7.365)$ \\
\hline \multirow[t]{2}{*}{ Havekid } & $0.058^{* * *}$ & $0.048^{* *}$ & $0.069^{* *}$ & $0.068^{* * *}$ & $0.048^{* * *}$ \\
\hline & (5.994) & $(2.212)$ & (2.036) & $(4.342)$ & (3.375) \\
\hline \multirow[t]{2}{*}{ Income } & $0.034^{* * *}$ & $0.035^{* *}$ & $0.030^{* * *}$ & $0.043^{* * *}$ & $0.033^{* * *}$ \\
\hline & (12.674) & $(2.565)$ & (4.005) & (7.882) & (9.655) \\
\hline \multirow[t]{2}{*}{ GDP } & $0.040^{* * *}$ & $0.028^{* * *}$ & $0.039^{* * *}$ & $0.035^{* * *}$ & $0.055^{* * *}$ \\
\hline & $(9.441)$ & $(2.582)$ & $(2.715)$ & $(4.867)$ & (9.438) \\
\hline \multirow[t]{2}{*}{ Population } & $-0.020^{* * *}$ & $-0.022^{* *}$ & $0.017^{*}$ & $-0.021^{* * *}$ & $-0.009^{* *}$ \\
\hline & $(-7.157)$ & $(-2.110)$ & (1.683) & $(-4.013)$ & $(-2.387)$ \\
\hline \multirow[t]{2}{*}{ atanhrho_12 } & $-0.863^{* * *}$ & $-1.101^{* *}$ & $0.579^{* * *}$ & $-0.644^{* * *}$ & $-0.934^{* * *}$ \\
\hline & $(-15.308)$ & $(-2.317)$ & (3.634) & $(-3.851)$ & $(-18.992)$ \\
\hline N & 158,524 & 69,549 & 19,967 & 89,516 & 69,008 \\
\hline
\end{tabular}

Notes. Table 8 reports the CMP regression results. Column (1) reports the results of the full sample. The sample in column (2) is the population who migrated from a region with a lower GDP per capita to a region with a higher GDP per capita; column (3) is the population who migrated from a region with a higher GDP per capita to a region with a lower GDP per capita. The sample in column (4) is migrants who moved across two different provinces; column (5) is migrants who moved within a province. Variable "city integration" here is constructed using fuzzy set theory. $z$ statistics are in parentheses. ${ }^{*}, * *$, and ${ }^{* * *}$ represent the significance level at $10 \%, 5 \%$ and $1 \%$ respectively

Column (1) in Table 8 shows the full sample's regression results. The results of the first stage are not reported; the first instrumental variable "Unemprate" is positively correlated with "Integration," and the second instrumental variable "Pulimit" is negatively correlated with "Integration," both of which are significant at the $1 \%$ level. The prior assumptions are validated. Columns (2)-(3) are the CMP regression results in the migration direction heterogeneity subsamples, and columns (4)-(5) are the CMP regression results in the migration range heterogeneity subsamples. All the results are consistent with the previous Ologit regression results. The endogenous test parameters 
atanhrho_12 are significantly different from 0 at the $1 \%$ level, indicating that "Integration" is indeed an endogenous variable and the CMP method is indeed applicable. The results above provide further support for all the hypotheses in this paper.

\section{Redefinition of City integration}

The city integration variable noted above is constructed based on fuzzy set theory. We then use the Principal Component Analysis (PCA) to remeasure this main variable and retest all the hypotheses as robustness tests. The core of the PCA method is

Table 9 CMP regression results with the redefinition of city integration (PCA method)

\begin{tabular}{|c|c|c|c|c|c|}
\hline & \multirow{2}{*}{$\begin{array}{l}\text { Full } \\
\text { sample } \\
\text { (1) }\end{array}$} & \multicolumn{2}{|c|}{ Migration direction heterogeneity } & \multicolumn{2}{|c|}{$\begin{array}{l}\text { Migration distance } \\
\text { heterogeneity }\end{array}$} \\
\hline & & $\begin{array}{l}\text { (2) migration with } \\
\text { an "ascending" } \\
\text { experience }\end{array}$ & $\begin{array}{l}\text { (3) migration } \\
\text { with a "falling" } \\
\text { experience }\end{array}$ & $\begin{array}{l}\text { (4) migration } \\
\text { over a longer } \\
\text { distance }\end{array}$ & $\begin{array}{l}\text { (5) } \\
\text { migration } \\
\text { over a shorter } \\
\text { distance }\end{array}$ \\
\hline \multirow[t]{2}{*}{ Integration $(P C A)$} & $1.290^{* * *}$ & $0.981^{* * *}$ & $1.104^{* * *}$ & $1.073^{* * *}$ & $1.526^{* * *}$ \\
\hline & $(26.835)$ & $(4.376)$ & $(4.706)$ & $(8.348)$ & $(42.526)$ \\
\hline \multirow[t]{2}{*}{ Buyhouse } & $0.335^{* * *}$ & $0.400^{* * *}$ & $0.288^{* * *}$ & $0.371^{* * *}$ & $0.274^{* * *}$ \\
\hline & $(31.448)$ & (20.819) & $(8.912)$ & $(22.872)$ & $(20.427)$ \\
\hline \multirow[t]{2}{*}{ Integration $(P C A) \times$ Buyhouse } & $-0.084^{* * *}$ & $-0.150^{* * *}$ & -0.024 & $-0.123^{* * *}$ & $-0.036^{*}$ \\
\hline & $(-5.230)$ & $(-5.332)$ & $(-0.450)$ & $(-5.021)$ & $(-1.772)$ \\
\hline \multirow[t]{2}{*}{ Age } & $-0.009^{* * *}$ & $-0.008^{* *}$ & -0.009 & $-0.007^{* *}$ & $-0.011^{* * *}$ \\
\hline & $(-3.828)$ & $(-2.019)$ & $(-1.237)$ & $(-2.052)$ & $(-3.359)$ \\
\hline \multirow[t]{2}{*}{ Age_sa } & $0.000^{* * *}$ & $0.000^{* * *}$ & 0.000 & $0.000^{* * *}$ & $0.000^{* * *}$ \\
\hline & (3.958) & $(2.782)$ & $(1.250)$ & $(2.722)$ & $(2.731)$ \\
\hline \multirow[t]{2}{*}{ Eduyear } & $-0.025^{* * *}$ & $-0.033^{* * *}$ & $-0.019^{* * *}$ & $-0.030^{* * *}$ & $-0.018^{* * *}$ \\
\hline & $(-21.399)$ & $(-17.718)$ & $(-5.363)$ & $(-18.670)$ & $(-11.172)$ \\
\hline \multirow[t]{2}{*}{ Gender } & $0.056^{* * *}$ & $0.058^{* * *}$ & $0.061^{* * *}$ & $0.057^{* * *}$ & $0.047^{* * *}$ \\
\hline & (9.903) & $(6.504)$ & (3.399) & (7.187) & (6.138) \\
\hline \multirow[t]{2}{*}{ Marriage } & $0.129^{* * *}$ & $0.128^{* * *}$ & $0.130^{* * *}$ & $0.127^{* * *}$ & $0.139^{* * *}$ \\
\hline & (9.197) & $(5.952)$ & (2.968) & (6.609) & (7.010) \\
\hline \multirow[t]{2}{*}{ Havekid } & $0.084^{* * *}$ & $0.088^{* * *}$ & $0.078^{* *}$ & $0.088^{* * * *}$ & $0.069^{* * *}$ \\
\hline & $(6.708)$ & $(4.569)$ & (2.032) & (5.132) & (3.876) \\
\hline \multirow[t]{2}{*}{ Income } & $0.047^{* * *}$ & $0.059^{* * * *}$ & $0.036^{* * *}$ & $0.052^{* * *}$ & $0.044^{* * *}$ \\
\hline & (15.043) & (11.131) & (4.384) & (11.820) & (10.494) \\
\hline \multirow[t]{2}{*}{ GDP } & $0.056^{* * *}$ & $0.044^{* * *}$ & $0.036^{* *}$ & $0.044^{* * *}$ & $0.086^{* * *}$ \\
\hline & (9.889) & (3.566) & $(2.136)$ & (4.898) & $(12.120)$ \\
\hline \multirow[t]{2}{*}{ Population } & $-0.022^{* * *}$ & $-0.037^{* * *}$ & $0.023^{* *}$ & $-0.023^{* * *}$ & 0.002 \\
\hline & $(-6.202)$ & $(-5.728)$ & (2.008) & $(-4.402)$ & $(0.326)$ \\
\hline \multirow[t]{2}{*}{ atanhrho_12 } & $-0.350^{* * *}$ & -0.153 & -0.223 & $-0.207^{* * *}$ & $-0.558^{* * *}$ \\
\hline & $(-10.087)$ & $(-1.164)$ & $(-1.529)$ & $(-2.638)$ & $(-16.289)$ \\
\hline N & 158,524 & 69,549 & 19,967 & 89,516 & 69,008 \\
\hline
\end{tabular}

Notes. Table 9 reports the CMP regression results. Column (1) shows the results of the full sample. The sample in column (2) is the population who migrated from a region with a lower GDP per capita to a region with a higher GDP per capita; column (3) is the population who migrated from a region with a higher GDP per capita to a region with a lower GDP per capita. The sample in column (4) is migrants who moved across two different provinces; column (5) is migrants who moved within a province. The variable "city integration" here is constructed using the PCA method. $z$ statistics are in parentheses. ${ }^{*}, *$, and ${ }^{* * *}$ represent the significance level at $10 \%, 5 \%$ and $1 \%$ respectively 
reduced-dimension and we choose 6 principal components from all the 9 sub-indices of city integration. The overall Kaiser-Meyer-Olkin equals to 0.7 which means that it is suitable to use PCA for the analysis. As well, the correlation between integration constructed using fuzzy set theory and using PCA is positive and significant at 0.903 . Then we use CMP to re-estimate all the hypotheses specifically. The estimated results are reported in Table 9, which are coincident with that in Table 8. It indicates that our regression results are still robust when we adjust the definition of city integration.

\section{Conclusions and policy suggestions}

This paper systematically investigates the cooperative relationship between homeownership, city integration and migrants' sense of happiness.

Firstly, there is a negative synergetic effect of housing purchase and city integration on sense of happiness, which still exists when all the control variables are added in. Secondly, we further explore the synergetic relationship between housing status, city integration and sense of happiness in heterogeneous migrants' subsamples. Compared with migrants who moved from developed areas to less developed areas, this negative synergetic effect is greater in migrants who moved from underdeveloped areas to developed areas. Similarly, compared with people who migrated shorter distances, this negative synergy impact on those who migrated further is more obvious. Thirdly, considering that the benchmark regression model might have problems such as omitted variables and endogeneity, this paper introduces appropriate instrumental variables such as the original regions' urban unemployment rate in 2012 and whether or not destination regions had a housing purchase restriction policy in 2012 and then uses the CMP method to re-estimate all the hypotheses. As well, considering the main variable in this paper-city integration is constructed from multiple-dimensional indices, we try to use PCA to reduce the dimension specifically and then to estimate all the hypotheses again. Finally, we find that the results are consistent with the results of the benchmark Ologit regressions.

The empirical results reveal that in general, renting houses reduces migrants' sense of happiness. However, greater city integration increases renters' sense of happiness more than home owners because they are starting at a lower level of happiness. Therefore, a city integration mechanism where housing status impacts the sense of residents' sense of happiness is supported.

Migrants mostly choose to rent a living place in the transition period when they first arrive in a new and unfamiliar city. In order to help migrants improve their sense of happiness more effectively and efficiently, attention to the city integration of migrants who are renters, especially those renters with "ascending" migration experiences or longer distance migration experiences, is of great necessity.

Specifically, from the national housing system perspective, a housing mechanism that meets both purchase and rental purposes and meets housing demand from new urban populations is vital and necessary. Governments should gradually explore a system whereby tenants enjoy the same rights as home buyers, deepen the reform of the housing rental market, guarantee tenants the same employment opportunities and benefits as registered permanent residents in the labor market, and guarantee renters' rights and interests in basic public services such as school enrollment for their children, medical insurance, and so on. Secondly, from the social and economic integration 
perspective, local governments, especially governments in first-tier cities and eastern coastal cities, should be encouraged to reform the housing supply system with the market playing the leading role in catering to multilayered demand while the government takes care of basic housing demand. Governments should provide various forms of rental housing, such as public rental houses and low-rent houses for migrants who do not yet own their own houses. It is recommended that governments ensure that housing is provided for all people and that they help migrants, especially renters, improve their city integration level. Thirdly, from the cultural integration perspective, local governments should strengthen regulations of rental building common areas by setting up autonomous management organizations. For instance, communities can encourage migrants to actively participate in local elections and various forms of sports activities, improve their integration motivation and process, and help them realize self-development and self-value. Eventually, from the psychological integration perspective, given that mass population migration can stimulate the nation's economy (Bove and Elia 2017), it is essential that people with permanent household registration eliminate discrimination and exclusion of migrants and enhance their mutual trust.

\section{Endnotes}

${ }^{1}$ School fees are one of the ways in which migrants are excluded from some cities. Due to the scarcity of education resources, public schools generally recruit students with local hukou while migrants without hukou are charged for admission.

${ }^{2}$ We thank an anonymous referee's input about distinguishing whether migrants have purchased housing in their city of residence or in other cities (e.g., for investment or for left-behind family members). Our dataset only shows the migrants' housing type in places where they live and there is no information about whether they have houses in other cities. We believe that owning a house that is a primary residence is more relevant to integration in that place of residence. Therefore, we think that owning a non-primary residence house would have a negligible effect on migrants' sense of happiness.

${ }^{3} \mathrm{We}$ appreciate the suggestions from an anonymous referee and attempt to more clearly explain the possible correlation between city integration and homeownership.

Funding

This paper was partially funded by National Natural Sciences Foundation of China, No. 71672190.

Availability of data and materials

If anyone is interested, please contact the author: zhangsihan2016@ruc.edu.cn.

Authors' contributions

SHZ carried out the model setup, performed the statistical analysis and drafted the manuscript. CLH participated in the research design and data processing. JC participated in its design, revised the manuscript and provided guidance on the details. All authors read and approved the final manuscript.

Authors' information

Sihan ZHANG is a PhD candidate in School of Business, Renmin University of China, and her research interests cover housing economics and urban economics. Chuanlu Hou is a PhD candidate in College of Economics, Jinan University, and his research interests are mainly on the regional economics. Jing Chen, PhD, is an associated professor in Accounting School, Capital University of Economics and Business, and her research interests cover real estate and China economy. 


\section{Publisher's Note}

Springer Nature remains neutral with regard to jurisdictional claims in published maps and institutional affiliations.

\section{Author details}

${ }^{1}$ Renmin Business School, Renmin University of China, Address: No. 59, Zhongguancun Avenue, Haidian District, Beijing 100872, People's Republic of China. ${ }^{2}$ College of Economics, Jinan University, Guangzhou, China. ${ }^{3}$ Accounting School,

Capital University of Economics and Business, Beijing, China.

Received: 31 May 2018 Accepted: 3 January 2019

Published online: 21 January 2019

\section{References}

Anderson, I. (1993). Housing policy and street homelessness in Britain. Housing Studies, 8(1), 17-28.

Barro, R. J. (1990). Government spending in a simple model of endogenous growth. Journal of Political Economy, 98(5), 103126.

Bostic, R., Gabriel, S., \& Painter, G. (2009). Housing wealth, financial wealth, and consumption: New evidence from micro data. Regional Science \& Urban Economics, 39(1), 79-89.

Bove, V., \& Elia, L. (2017). Migration, diversity, and economic growth. World Development, 89, $227-239$.

Bucchianeri, G. (2009). The American dream? The private and external benefits of homeownership, Working Paper, The Wharton School of Business.

Carpentier, J., \& Sablonnière, R. D. L. (2013). Identity profiles and well-being of multicultural immigrants: The case of Canadian immigrants living in Quebec. Frontiers in Psychology, 4(2), 80.

Dorvil, H., Morin, P., Beaulieu, A., \& Robert, D. (2005). Housing as a social integration factor for people classified as mentally III. Housing Studies, 20(3), 497-519.

Gan, J. (2010). Housing wealth and consumption growth: Evidence from a large panel of households. Review of Financial Studies, 23, 2229-2267.

Haurin, D., Parcel, T., \& Haurin, R. (2002). Does homeownership affect child outcomes. Real Estate Economics, 30(4), 635-666.

Knight, J., Song, L., \& Gunatilaka, R. (2009). Subjective well-being and its determinants in rural China. China Economic Review, 20(4), 635-649.

Kusmin, L. D. (2007). Rural America at a glance: 2007 edition. Economic Information Bulletin.

Lelli, S. (2001). Factor analysis vs fuzzy sets theory: Assessing the influence of different techniques on Sen's functioning approach. Leuven: Center for Economic Studies of K.U Working Paper, No. 21.

Li, T. 李涛, Shi, Y.P. 史宇鹏, \& Chen, B.K. 陈斌开. (2011). 住房与幸福:幸福经济学视角下的中国城镇居民住房问题 (Homeownership and happiness: Theory and evidence from China from the perspective of happiness economics). 经济 研究 (Economic Research Journal), 46(9), 69-82.

Li, T. C., Chu, C. C., Meng, F. C., Li, Q., Mo, D., Li, B., \& Tsai, S. B. (2018). Will happiness improve the psychological integration of migrant workers? International Journal of Environmental Research and Public Health, 15(5), 900-922.

Lian, Y.J. 连玉君, Li, W.S. 黎文素, \& Huang, B.H. 黄必红. (2014). 子女外出务工对父母健康和生活满意度影响研究 (The impact of children migration on the health and life satisfaction of parents left behind). 经济学(季刊)(China Economic Quarterly), 14(1),185-202.

Lu, F. W. 路方文, Liu, G. E. 刘国恩, \& Li, H. W. 李辉文. (2017). 子女性别与父母幸福感 (The gender of children and parents sense of happiness). 经济研究 (Economic Research Journal), 52(10),173-188.

Michelacci, C., \& Silva, O. (2007). Why so many local entrepreneurs. Review of Economics \& Statistics, 89(4), 615-633.

Murphy, R. (2002). How migrant labor is changing rural China. Cambridge: Cambridge University Press.

Pleace, N. (1998). Single homelessness as social exclusion: The unique and the extreme. Social Policy and Administration, 32(1), 46-59.

Qin, L.J. 秦立建, \& Chen, B. 陈波. (2014). 医疗保险对农民工城市融入的影响分析 (An analysis on the impact of medical insurance on migrant workers' urban integration). 管理世界 (Management World), 30(10),91-99.

Rohe, W. M., \& Stegman, M. A. (1994). The impact of home ownership on the social and political involvement of low-income people. Urban Affairs Quarterly, 30(1), 152-172

Roodman, D. (2011). Fitting fully observed recursive mixed-process model with CMP. The Stata Journal, 29(2), 159-206.

Spoonley, P., Peace, R., Butcher, A., \& O'Neill, D. (2005). Social cohesion: A policy and indicator framework for assessing immigrant and host outcomes. Social Policy Journal of New Zealand, 24(1), 85-110.

Stephen, O., \& Ezati, B. A. (2017). Parents' contributions towards education process and variations in school performance indices (SPI) in Uganda certificate of education (UCE) examinations in central and northern Uganda. Journal of Education \& Social Policy, 4(2), 80-96.

Sun, S.B. 孙三百.(2016). 城市移民收入增长的源泉:基于人力资本外部性的新解释 (The source of urban immigrants' income growth in China: A new explanation from the perspective of human capital externality). 世界经济 (The Journal of World Economy), 39 (4),170-192.

Wang, W. W., \& Fan, C. C. (2006). Success or failure: Selectivity and reasons of return migration in Sichuan and Anhui, China. Environment and Planning, 38(5), 939-958.

Wang, Z., Graaff, T. D., \& Nijkamp, P. (2015). Cultural diversity and cultural distance as choice determinants of migration destination. Spatial Economic Analysis, 11(2), 176-200

Whelan, S. (2017). Does homeownership affect education outcomes? IZA World of Labor. https://doi.org/10.15185/izawol.342.

Yang, J.H. 杨菊华. (2015). 中国流动人口的社会融入研究 (Research on the assimilation of the floating population in China). 中国社会科学 (Social Sciences in China), 36(2),61-79.

Yu, L., Yin, X., Zheng, X., \& Li, W. (2016). Lose to win: Entrepreneurship of returned migrants in China. The Annals of Regional Science, 58(2), 341-374

Zadeh, L. A. (1965). Fuzzy sets. Information and Control, 8(3), 338-353. 